\title{
Chromosome Numbers of Four Nigerian Species of Cola Schott. \& Endlicher (Sterculiaceae).
}

\author{
By P. O. Adebola ${ }^{1, *}$ and J. A. MoraKinYo ${ }^{2}$
}

(Received $4^{\text {th }}$ April 2005)

\begin{abstract}
This paper reports the results of chromosome countings in four wild Cola species (Cola lateritia, C. ballayi, $C$. verticillata and $C$. gigantea). Cytological investigation of these species gave a constant mitotic chromosome counts of $2 \mathrm{n}=4 \mathrm{x}=40$ for the first time. The karyotypes were found to consist mostly of metacentric and submetacentric chromosomes. In addition to confirming the chromosome numbers and ploidy levels in these species, the results also reveals high symmetry and homogeneity of the karyotypes with those of the cultivated species (C. nitida and C. acuminata) already reported. The similarity in chromosome morphology between the cultivated and wild species indicate their common origin and suggests the possibility of using these wild species as bridges for gene transfer in Cola breeding programmes involving interspecific hybridization.
\end{abstract}

Key words: Cola, wild species, chromosome counts, karyotype.

\section{Introduction}

The genus Cola Schott and Endl. belongs to the family Sterculiaceae and is one of the economically important genera of this family. According to BODARD (1962) the genus comprises about 90 species of which 50 have been described in West Africa. Two of these species, Cola niti$d a$ (Vent) Schott \& Endl. and Cola acuminata (Pal. de Beauv) Schott. \& Endl. are of major economic importance in Nigeria. Both species bear a striking resemblance to each other and are cultivated for their edible seeds (Kolanuts). In Nigeria, the genus is also represented by several other wild relatives occurring throughout the rain forest and southern guinea savannah belt. Among these, Cola lateritia, C. ballayi, C. verticillata and $C$. gigantea occupies outstanding position because they possess many attributes of agronomic importance that are not found in the cultivated species. The large variability in the germplasm of these wild species therefore, offers opportunities for the exploitation of useful genes from them for the improvement of the cultivated species. This is a constant objective of plant breeding and is pursued through several techniques. However, before this notable goal is achieved, basic cytological information on these plants is very essential. Cytological data on Cola is scarce and in many cases is lacking. Only isolated chromosome counts in a few species (C. lepidota, C. millenii, C. nitida,

1) Plant Breeding Group, Cocoa Research Institute of Nigeria, PMB 5244, Ibadan, Nigeria.

2) Plant Science Unit, Department of Biological Sciences, University of Ilorin, PMB 1515, Ilorin, Nigeria.

*) Author for correspondence, current address: P. O. Box 95, Alice 5700, South Africa; phone: +27723223647 ; fax +27406022323 ; email: padebola@ufh.ac.za
C. acuminata) have been reported (MoRAKINYO, 1978; MorakinYo and Olorode, 1984; MorakinYo, 1995). To our knowledge, no cytogenetic information on other Cola species has been published. This paper reports the first results of chromosome countings in four wild species of Cola in South Western Nigeria.

\section{Materials and Methods}

Mature nuts of Cola lateritia, C. ballayi, $C$. verticillata and $C$. gigantea were collected from the germplasm plots of Cocoa Research Institute of Nigeria, Idi-Ayunre Ibadan (Lat. $07^{0} 10^{1} \mathrm{~N}$ Long. $03^{0} 52^{1} \mathrm{E}$ ) where a collection of wild Cola germplasm were established. Voucher specimens of the studied plants were also deposited in the institute's herbarium.

For the study of somatic chromosomes, mature nuts of the plants studied were harvested and planted in Petri dishes lined with moist filter paper. They were then kept in a dark cupboard until they germinated. Planting in germinating trays containing mixture of sand and sawdust did not give the required results.

Root tips about 2-5 $\mathrm{mm}$ long were harvested from young seedlings and transferred into a fixative $(1: 3 \mathrm{v} / \mathrm{v}$ ratio of acetic/alcohol) for 24 hours after pretreatment for about 2 hours in saturated solution of Paradichlorobenzene (PDB). The materials were then refrigerated until use. When root tips were needed for squashing, they were removed from the refrigerator, rinsed in two quick changes of distilled water and hydrolyzed for 40 minutes in $1 \mathrm{~N} \mathrm{HCl}$ at room temperature. They were thereafter rinsed in distilled water and stained for 15 minutes in FLP - Orcein stain (JACKSON, 1973). Squashing was done by gently taping the cover slip with the end of a ballpoint. Alternate heating and cooling of the slide after squashing was done by passing it over the flame of a spirit burner to ensure good spread and well stained chromosome (BARONE and SACCARDO, 1990).

Slides were observed with the aid of a Zeiss binocular microscope equipped with photographic facilities. Photomicrographs were taken from suitable squashes and chromosome counts at pro-metaphase and metaphase stages were made. Chromosome arm and total length were measured with calibrated eyepiece graticule. The centromeric index was determined according to the method of LEVAN et al. (1964) and as modified by OYEWOLE (1972). At least 10 metaphase cells were analyzed per species.

\section{Results and Discussion}

Cytological investigation gave a constant mitotic chromosome counts of $2 \mathrm{n}=40$ for Cola ballayi, Cola lateritia, 

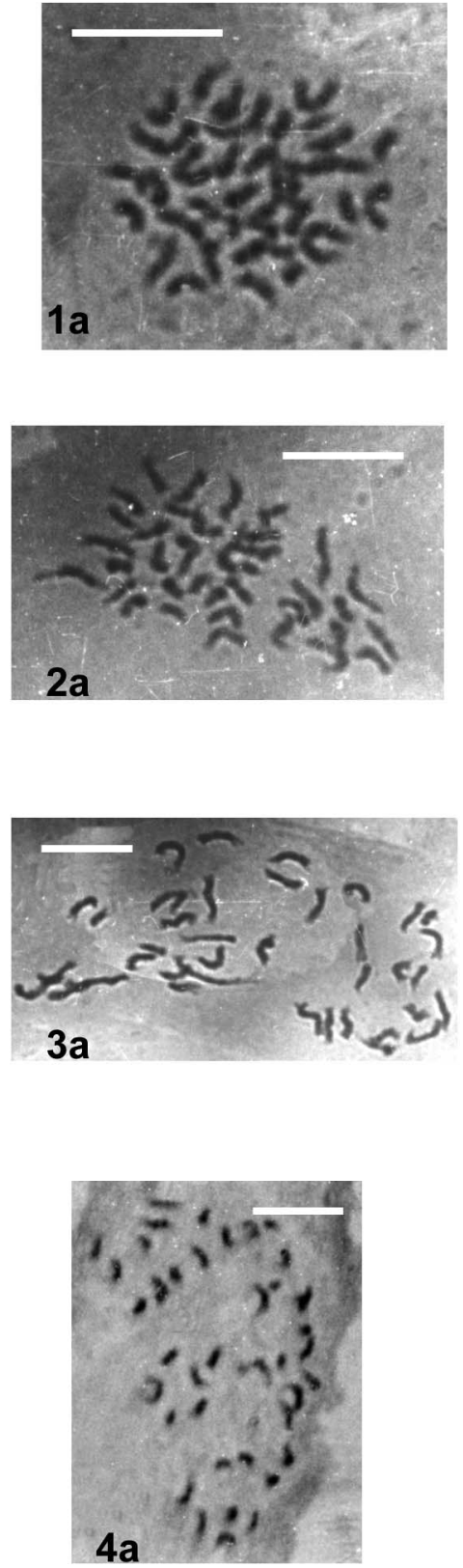

Figure 1 to 4. - Photomicrographs (a) and corresponding schematic diagram (b) of mitotic chromosomes showing diploid number of $2 \mathrm{n}=40$ in Cola ballayi (Fig. 1); Cola gigantea (Fig. 2); pro-metaphase chromosomes of Cola verticillata (Fig. 3) and Cola lateritia (Fig. 4). Scale bar equal to $10 \mu \mathrm{m}$.
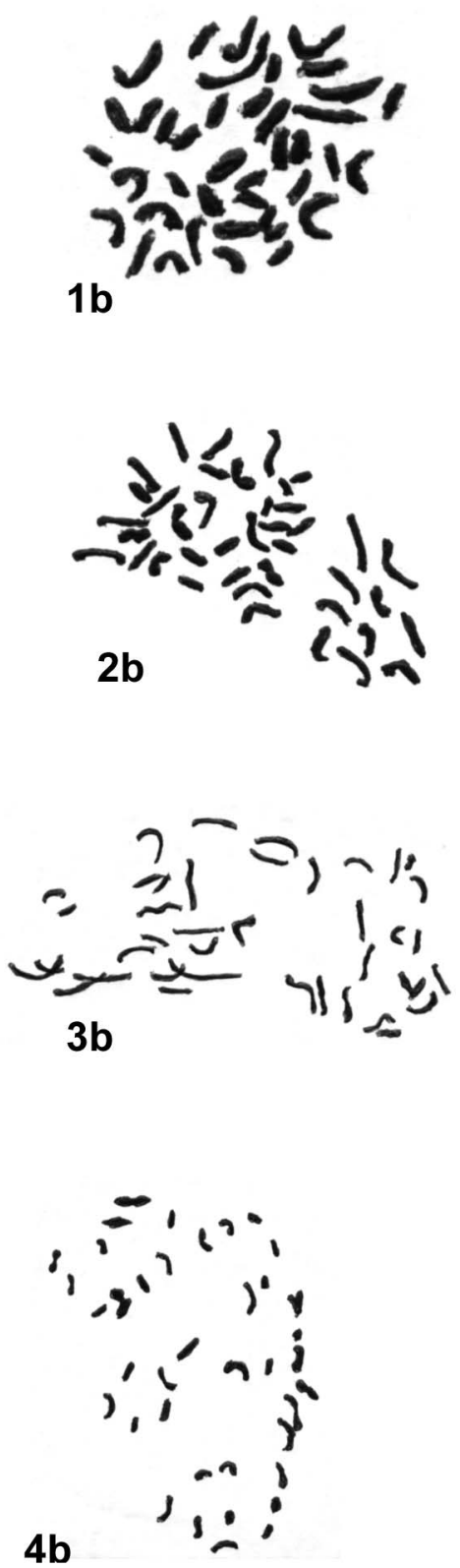

Cola gigantea and Cola verticillata. This mitotic chromosome count is the first report in these species. Earlier counts of $2 \mathrm{n}=40$ for $C$. millenii, $C$. nitida, $C$. acuminata and $C$. lepidota have been reported by MoRAKINYO (1978) confirming that the two cultivated species of Cola (C. nitida and C. acuminata) and the studied wild relatives possess the same number of chromosomes $(2 \mathrm{n}=$ 40). According to Purseglove (1968), the basic chromosomes number of Cola is $\mathrm{X}=10$ indicating that these species are probably polyploids of $2 \mathrm{n}=4 \mathrm{x}=40$ with each chromosome represented four times in the somatic complement. The chromosome morphology in these species was very similar especially with regards to the range and gradation of chromosome length and the position of the centromere. The metaphase chromosomes were generally small in size making it impossible to perform detailed karyotypic analysis. Chromosome size ranges from 2.0 to $7.1 \mathrm{\mu m}$. However, cells at prometaphase stages proved to be useful for chromosome counts, as the chromosomes appear longer and more distinctive. Figs. 1 to 4 show the photomicrographs of mitotic chromosomes of these Cola species and their corresponding schematic drawings. The chromosomes are mostly metacentric and sub-metacentric. Regular mitotic cell division was observed in all the species and none of them showed evidence of chromosomal aberrations. Chromosomes appeared generally small in size, making it difficult to see their morphological details. The small chro- 
mosome size is not only peculiar to the species observed in this study, but has also been reported for other species of the genus by MORAKINYO (1995), confirming that this is a distinct karyotypic feature of the genus Cola.

The similarity in chromosome morphology of these species is very evident, especially chromosome staining intensity, the range and gradation of chromosome length and the centromeric positioning. It also partly explains the high degree of morphological similarity in the species indicating, their common origin. The similarity in chromosome morphology suggests that the species are somehow related, as pointed out by FADEN and SUDA (1980). Gene exchange among these species is therefore expected in the absence of cryptic structural differences in the chromosome genic differences and other pre- and postzygotic cross breeding barriers. The wild species reported here may therefore, be useful as bridge species for gene transfer in Cola breeding programmes involving interspecific hybridization.

\section{Acknowledgements}

This paper is published with the permission of the Director/Chief Executive, Cocoa Research Institute of Nigeria (CRIN).

\section{References}

BARone, A. and F. SACCARdo (1990): Pachytene morphology of cowpea chromosome. P.137-143 In N.Q. Ng and L.M. Monti (eds). Cowpea genetic resources, IITA, Ibadan. 200pp.
BoDARD, M. (1962): Contributions a l'etude systematique sur le Cola en Afrique occidentale. Annales le la faculte des sciences de l'Universite de Dakar, Tome 7: 71-82.

FADEN, R. B. and Y. SUDAN (1990): Cytotaxonomy of Commeliaceae: chromosome number of some African and Asiatic species. Botanical Journal of the Linnean Society 81: 301-325.

JACKSON, R. C. (1973): Chromosome evolution in Haploppapus gracilis: a centric transposition race. Evolution 27: 243-256.

Levan, A., K. Fredga and A. A. SANDBERg (1964): Nomenclature for centromeric position of chromosomes. Hereditas 52: 201-220.

MoRAKInYo, J. A. (1978): Biosystematics Studies in the genus Cola Schott and Endlicher. M.Sc. dissertation, University of Ife, Nigeria.

MoRAKINYo, J. A. (1995): Gene exchange between Cola millenii and Cola nitida: Hybridization and hybrid seed viability. Bioscience Research Communications. Vol. 7 (2), 151-153.

MorakinYo, J. A and O. Olorode (1984): Cytogenetic and Morphological studies on Cola acuminata (P. Beauv.) Schott \& Endlicher; Cola nitida (Vent) Schott \& Endlicher and the C. acuminata x C. nitida F1 Hybrid. Cafe, Cacao, The. Vol. xxviii (4), 1984.

Oyewole, S. O. (1972): Taxonomic treatment of Urginea altilissima Baker in West Africa. Bio. Soc. Biot. (Zeserie) 49: 168-172.

Purseglove, J. W. (1968): Tropical Crops. Dicotyledons. The English language Book Society and Longman. 322pp.

\footnotetext{
Herausgeberin: Bundesforschungsanstalt für Forst- und Holzwirtschaft: Schriftleitung: Institut für Forstgenetik und Forstpflanzenzüchtung, Siekerlandstrasse 2, D-22927 Grosshansdorf — Verlag: J. D. Sauerländer's Verlag, Finkenhofstrasse 21, D-60322 Frankfurt a. M. Anzeigenverwaltung: J. D. Sauerländer's Verlag, Frankfurt am Main.
} Satz: Satz- und Grafikstudio König, Marburg — Druck: Druckerei Wenzel, Marburg — Printed in Germany. 